Provided for non-commercial research and education use. Not for reproduction, distribution or commercial use.

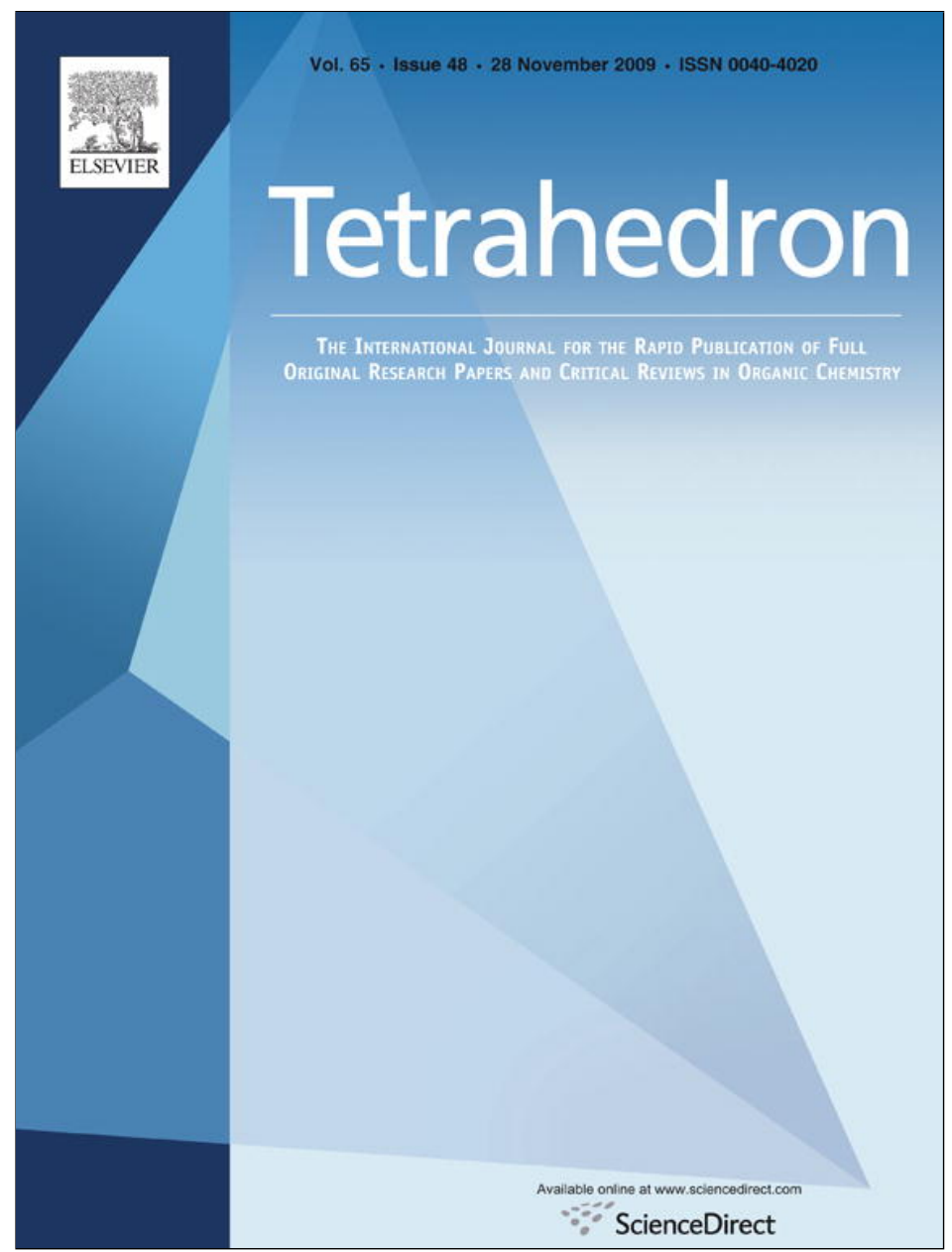

This article appeared in a journal published by Elsevier. The attached copy is furnished to the author for internal non-commercial research and education use, including for instruction at the authors institution and sharing with colleagues.

Other uses, including reproduction and distribution, or selling or licensing copies, or posting to personal, institutional or third party websites are prohibited.

In most cases authors are permitted to post their version of the article (e.g. in Word or Tex form) to their personal website or institutional repository. Authors requiring further information regarding Elsevier's archiving and manuscript policies are encouraged to visit:

http://www.elsevier.com/copyright 


\title{
The $\alpha$-effect in cyclic secondary amines: new scaffolds for iminium ion accelerated transformations
}

\author{
John B. Brazier ${ }^{\mathrm{a}}$, Julie L. Cavill ${ }^{\mathrm{a}}$, Richard L. Elliott ${ }^{\mathrm{b}}$, Gareth Evans ${ }^{\mathrm{a}}$, Timothy J.K. Gibbs ${ }^{\mathrm{a}}$, Ian L. Jones ${ }^{\mathrm{a}}$, \\ James A. Platts ${ }^{a, *}$, Nicholas C.O. Tomkinson ${ }^{\mathrm{a}, *}$ \\ ${ }^{a}$ School of Chemistry, Main Building, Cardiff University, Park Place, Cardiff, CF10 3AT, UK \\ ${ }^{\mathrm{b}}$ Medicinal Chemistry, GlaxoSmithKline, New Frontiers Science Park, Harlow, Essex, CM19 5AW, UK
}

\section{A R T I C L E I N F O}

\section{Article history:}

Received 29 July 2009

Received in revised form

16 September 2009

Accepted 2 October 2009

Available online 7 October 2009

\begin{abstract}
A B S T R A C T
Five-membered secondary amine heterocycles containing an $\alpha$-heteroatom were prepared and shown to be ineffective as catalysts for the iminium ion catalysed Diels-Alder reaction between cinnamaldehyde and cyclopentadiene. Their six-membered counterparts proved to be highly active catalysts. In stark contrast, the catalytic activity observed when comparing the non $\alpha$-heteroatom cyclic amines proline methyl ester and methyl pipecolinate showed the five-membered ring amine was significantly more active. Concurrent density functional theoretical calculations suggest a rationale for the observed trends in reactivity, highlighting that LUMO activation through an iminium ion intermediate plays a key role in catalytic activity.
\end{abstract}

(c) 2009 Elsevier Ltd. All rights reserved.

\section{Introduction}

Since the original report by MacMillan in $2000,{ }^{1}$ the use of secondary amine catalysts in cycloaddition and conjugate addition reactions of $\alpha, \beta$-unsaturated aldehydes has provided an inspiring number of new bond-construction processes that proceed with remarkable levels of enantioselectivity. ${ }^{2}$ The majority of work reported within this vibrant area of research has focused on the development of new methods for bond-formation, rather than understanding catalyst activity ${ }^{3}$ and addressing the often high levels of catalyst loading. As the field matures and the number of applications expands, development will undoubtedly focus on the preparation of more active catalyst scaffolds with which to accelerate this class of transformation.

We have recently described the effects on catalyst activity of a heteroatom $\alpha$ - to the reactive secondary nitrogen centre, and have discovered a series of acyclic catalysts for the iminium ion catalysed Diels-Alder reaction. ${ }^{4}$ A combination of experimental and theoretical investigations have yielded a structure-reactivity relationship between amine structure and catalyst activity for the Diels-Alder reaction, which we are adopting with the ultimate goal of developing a predictive model for future rational catalyst design. ${ }^{5}$

\footnotetext{
* Corresponding authors. Tel.: +440 2920874068; fax: +44 02920874030.

E-mail addresses: Platts@cardiff.ac.uk (J.A. Platts), tomkinsonnc@cardiff.ac.uk (N.C.O. Tomkinson).
}

Previous synthetic investigations, as well as examination of the literature precedent, revealed two important trends relating the structure of the secondary amine and activity in the iminium ion catalysed Diels-Alder reaction. Firstly, cyclic secondary amines 3 give good levels of reactivity for these transformations. Secondly, the introduction of an $N$-methyl carbamate $\alpha$ - to the reactive nitrogen centre provided a catalyst $\mathbf{4}$ with the highest levels of activity to date, albeit in an achiral series. We wished to investigate if bringing together these two principal findings would lead to a further increase in catalyst activity, and set out to discover if a cyclic secondary amine incorporating an $\alpha$-heteroatom (such as $\mathbf{5}$ ) would provide a platform with which to generate state-of-the-art chiral catalysts for use in iminium ion catalysed transformations (Fig. 1).

\section{Results and discussion}

As a starting point for this investigation, we selected a series of target scaffolds 6-9 with which to test our original hypothesis. These fell into three distinct classes of compounds: the nature of the heteroatom (6 and 7); inclusion of an endo-cyclic electron withdrawing group (9); incorporation of an exo-cyclic electron withdrawing group (8) (Fig. 2).

The methods adopted to prepare these initial targets are outlined in Scheme $1{ }^{6}$ Treatment of $N$-Boc hydroxylamine 10 with $1,3-$ dibromopropane at reflux, under phase transfer conditions allowed access to the protected precursor to our target isoxazolidine in poor but acceptable yield (17\%). Removal of the Boc protecting group (89\%) using $\mathrm{HCl}$ in diethyl ether (2 M) gave our first target $\mathbf{6}$. The 


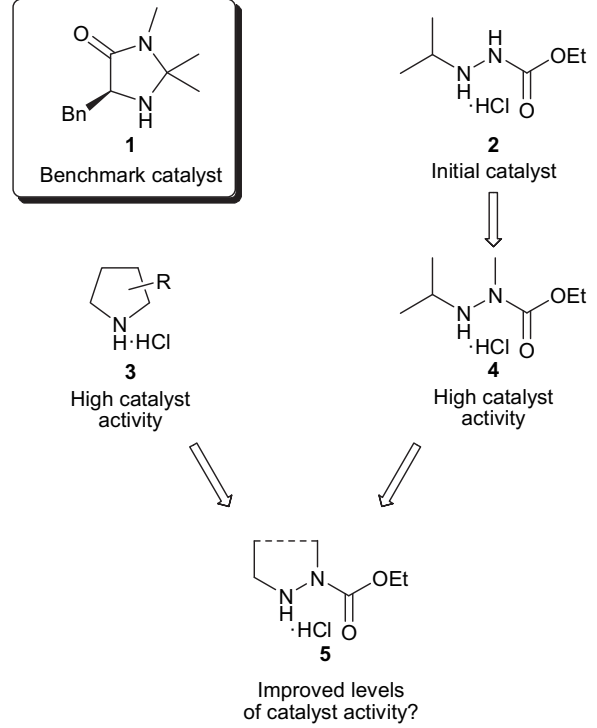

Figure 1. Design of potential catalysts.<smiles>Cl[X]1CCCN1</smiles>

$X=O 6$ $\mathrm{X}=\mathrm{NH} 7$<smiles>CC(C)(C)N1CCCN1</smiles>

8<smiles>O=C1CCNN1</smiles>

$\mathrm{X}=\mathrm{O}, \mathrm{NH}$

9
Figure 2. Initial target scaffolds.

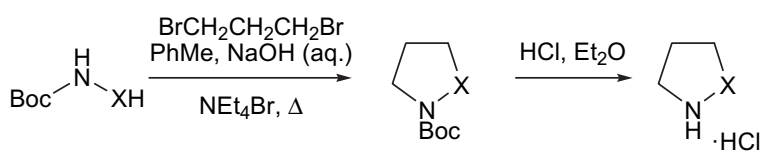

$$
\begin{array}{lll}
X=O 10 & X=O 12(17 \%) & X=O 6(89 \%) \\
X=N B o c 11 & X=N B o c 13(74 \%) & X=N H 7(96 \%)
\end{array}
$$

$$
\begin{aligned}
& \mathrm{H}_{2} \mathrm{~N}_{\mathrm{H}} \stackrel{\mathrm{O}}{\mathrm{O}} \\
& \underset{\text { 2. }(\mathrm{Boc})_{2} \mathrm{O}, \mathrm{THF}, \mathrm{O}^{\circ} \mathrm{C}}{\stackrel{\mathrm{BrCH}}{2} \mathrm{CH}_{2} \mathrm{CH}_{2} \mathrm{Br}} \\
& \mathrm{NEt}_{4} \mathrm{Br}, \Delta \\
& 14 \\
& \text { 3. } \mathrm{HCl}, \mathrm{Et}_{2} \mathrm{O} \text {, r.t. } \\
& \text { 1. } \mathrm{CbzCl}, \mathrm{CHCl}_{3} \text {, } \\
& \text { Boc }^{-\stackrel{H}{N}}-\mathrm{NH}_{2} \\
& \mathrm{NaOH} \text { (aq.), r.t. } \\
& \text { 2. } \mathrm{BrCH}_{2} \mathrm{CH}_{2} \mathrm{CH}_{2} \mathrm{Br} \\
& \mathrm{PhMe}, \mathrm{NaOH} \text { (aq.) } \\
& \mathrm{NEt}_{4} \mathrm{Br}, \Delta \\
& \text { 3. } \mathrm{HCl}, \mathrm{Et}_{2} \mathrm{O} \text {, r.t. }
\end{aligned}
$$

$$
\begin{aligned}
& \sum_{\mathrm{N}^{-}}^{\mathrm{N}}-\mathrm{CO}_{2} \mathrm{Et} \\
& 15(76 \%)
\end{aligned}
$$$$
\sum_{\mathrm{H}^{-}}^{-\mathrm{N}}-\mathrm{CO}_{2} \mathrm{Bn}
$$

$17(68 \%)$

Scheme 1. Preparation of five-membered ring hydrazides and hydroxylamines.

pyrazolidine hydrochloride $\mathbf{7}$ was prepared in an analogous procedure starting from di-Boc hydrazine $\mathbf{1 1}$ in a pleasing $71 \%$ overall yield. Our attention then turned to the inclusion of an electron withdrawing group on the $\alpha$-nitrogen (8), the introduction of which had been crucial to obtaining good levels of catalyst activity within previous work on acyclic catalysts. ${ }^{4}$ Boc protection of ethyl carbazate 14 proceeded smoothly to give the protected hydrazine in $97 \%$ yield with no purification required. This was subsequently reacted with 1,3-dibromopropane under phase transfer conditions to give the precursor to our target scaffold in $81 \%$ after purification. Finally, the Boc protecting group was removed with hydrochloric acid in diethyl ether. The hydrochloride salt $\mathbf{1 5}$ precipitated out of solution giving the desired catalyst in an overall yield of $76 \%$ for the three steps. Introduction of a benzyl carbamate $\alpha$ - to the reactive nitrogen was achieved in an analogous fashion. Cbz protection of tert-butyl carbazate 16 proceeded efficiently at room temperature (91\%) and the resulting protected hydrazine was then submitted to a cyclisation reaction with 1,3-dibromopropane followed by removal of the Boc protecting group to give $\mathbf{1 7}$ as a colourless solid in an overall yield of $68 \%$ for the three steps.

Considering catalysts bearing an endo-cyclic electron withdrawing group encompassing the generic template $\mathbf{9}$, it was envisaged that $\mathbf{1 8}$ could act as a Mannich base and therefore readily eliminate upon protonation, hence requiring preparation of a derivative such as $\mathbf{1 9}$ to circumvent this problem (Fig. 3). While preparing these catalysts, we became aware of a series of reports from Ogilvie showing the camphor derived hydrazide $\mathbf{2 0}$ to be effective for iminium ion catalysed Diels-Alder cycloaddition, the reactions proceeding with high e.e.'s. ${ }^{7}$ The kinetics of these reactions appeared significantly slower than those observed previously with our acyclic scaffolds (e.g., 4), such that we decided not to pursue structures such as $\mathbf{1 9}$ as potential catalysts.<smiles>O=C1CCNN1</smiles>

18<smiles>CC1(C)CNNC1=O</smiles>

19

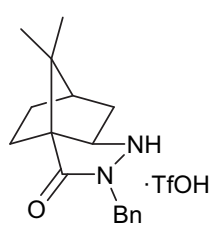

20
Figure 3. Endo-cyclic electron withdrawing groups.

Results of the Diels-Alder reaction of cinnamaldehyde $\mathbf{2 2}$ and cyclopentadiene 21 catalysed by the four new scaffolds $(6,7,15$, and 17) and our previously optimised acyclic catalyst $4^{5}$ are shown in Table 1.

Table 1

Diels-Alder reaction of five-membered ring catalysts ${ }^{\mathrm{a}}$

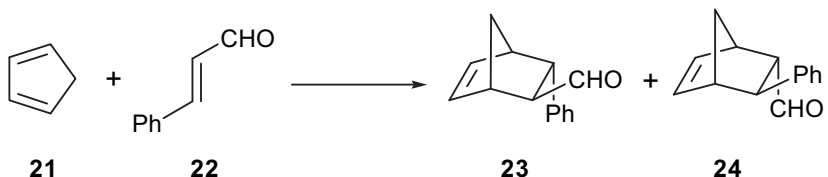

\begin{tabular}{llllc}
\hline Entry & Catalyst & Time & endo:exo $^{\text {c }}$ & \%Yield $^{\text {b }}$ \\
\hline 1 & None & 48 & $64: 36$ & 7 \\
2 & $\mathbf{4}$ & 6 & $35: 65$ & 98 \\
3 & $\mathbf{6}$ & 24 & $34: 66$ & 8 \\
4 & $\mathbf{7}$ & 24 & $55: 45$ & 15 \\
5 & $\mathbf{1 5}$ & 24 & $33: 67$ & 38 \\
6 & $\mathbf{1 7}$ & 24 & $32: 68$ & 34 \\
\hline
\end{tabular}

a All reactions carried out in methanol at $25{ }^{\circ} \mathrm{C}$ with $10 \mathrm{~mol} \%$ catalyst as their $\cdot \mathrm{HCl}$ salts.

b Isolated yield of $\mathbf{2 3} \& \mathbf{2 4}$ after chromatography and is the average of two catalytic runs.

${ }^{c}$ endo:exo ratios determined by ${ }^{1} \mathrm{H}$ NMR spectroscopy of the crude reaction mixtures.

Disappointingly, each of the five-membered cyclic secondary amines containing an $\alpha$-heteroatom (entries 3-6) were substantially less active than the acyclic hydrazide $\mathbf{4}$ (entry 2 ) under our standard reaction conditions. Consistent with previous observations, a nitrogen $\alpha$-heteroatom resulted in a more efficient catalyst when compared to its oxygen analogue (entries 3 and 4), and the introduction of the electron withdrawing group on the $\alpha$-heteroatom increased reactivity further (entries 5 and 6) suggesting 
a similar reactivity profile to that shown in the acyclic series. However, the level of catalytic activity was substantially less than that obtained with $\mathbf{4}$ (98\% yield, $6 \mathrm{~h}$ ). After the $24 \mathrm{~h}$ reaction period it was possible to isolate the catalyst ( $80 \%$ recovery), showing that reduced levels of activity were not due to decomposition. We conclude, therefore, that our original hypothesis of combining the $\alpha$-effect with a five-membered heterocycle does not lead to the desired levels of catalyst activity for this class of transformation.

Our attention then turned to preparation of a series of six-membered rings, in order to expand the range of heterocyclic catalysts and hence draw more general structure-reactivity relations. We prepared two six-membered cyclic hydrazides $\mathbf{2 6}(62 \%)$ and $\mathbf{2 8}(44 \%)$ in an analogous manner to that adopted previously (Scheme 2).

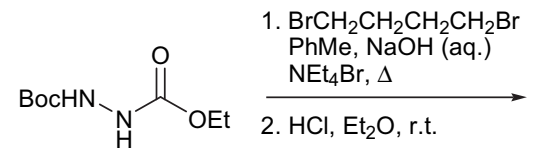

25

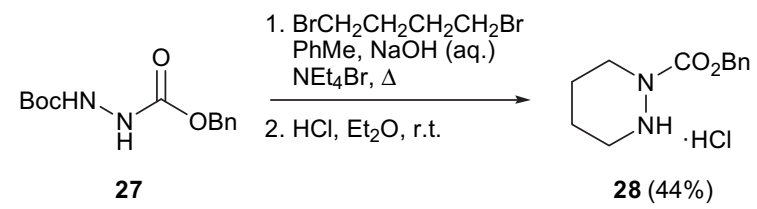

Scheme 2. Preparation of six-membered cyclic hydrazides.

Catalysts $\mathbf{2 6}$ and $\mathbf{2 8}$ were submitted to the standard Diels-Alder reaction conditions for $6 \mathrm{~h}$ (Table 2). The results showed excellent yields with near quantitative results being observed for both catalysts (entries 2 and 3). exo:endo ratios were in favour of the exoisomer, consistent with literature precedent for iminium ion catalysed Diels-Alder reactions of these substrates. ${ }^{1}$ Importantly, both catalysts exhibited higher conversions when compared to the commercially available imidazolidinone $\mathbf{1}$ (entry 4) under identical reaction conditions. With near quantitative results being observed with both catalysts after six hours we examined the performance limit of 26, altering both catalyst loading and reaction time (entries $5-8$ ), which revealed at $10 \mathrm{~mol} \%$ loading the reaction resulted in $90 \%$ isolated yield of the product after just $3 \mathrm{~h}$, a substantial increase in reactivity over our previously described system. Recovery of $\mathbf{2 6}$ from the crude reaction mixture using a Varian Mega Bond Elut ${ }^{\circledR}$ SCX column resulted in 92\% catalyst recovery, highlighting the stability of this class of scaffold to the reaction conditions employed.

Table 2

Diels-Alder reaction of six-membered ring catalysts ${ }^{\mathrm{a}}$

\begin{tabular}{|c|c|c|c|c|}
\hline Entry & Catalyst (loading) & Time & endo:exo ${ }^{c}$ & \%Yield ${ }^{\mathrm{b}}$ \\
\hline 1 & $4(10)$ & 6 & $35: 65$ & 98 \\
\hline 2 & $26(10)$ & 6 & $32: 68$ & 99 \\
\hline 3 & $28(10)$ & 6 & $32: 68$ & 94 \\
\hline 4 & $1(10)$ & 6 & 39:61 & 87 \\
\hline 5 & $26(1)$ & 3 & $30: 70$ & 14 \\
\hline 6 & $26(2)$ & 3 & $31: 69$ & 26 \\
\hline 7 & $26(5)$ & 3 & $32: 68$ & 50 \\
\hline 8 & $26(10)$ & 3 & $32: 68$ & 90 \\
\hline 9 & 29 (10) & 6 & $40: 60$ & $3^{d}$ \\
\hline 10 & $30(10)$ & 6 & $30: 70$ & 62 \\
\hline
\end{tabular}

a All reactions between cyclopentadiene and cinnamaldehyde carried out in methanol at $25^{\circ} \mathrm{C}$ with catalyst as $\cdot \mathrm{HCl}$ salt.

b Isolated yield of $\mathbf{2 3}$ \& $\mathbf{2 4}$ after chromatography and is the average of two catalytic runs.

c endo:exo ratios determined by ${ }^{1} \mathrm{H}$ NMR spectroscopy of the crude reaction mixtures.

${ }^{\mathrm{d}}$ Conversion estimated from ${ }^{1} \mathrm{H}$ NMR spectroscopy.
The precise reason(s) behind the finding that $\mathbf{2 6}$ (Table 2; entry 8) was more effective than the five-membered ring counterpart 15 (Table 1; entry 5) was not apparent. Examination of methyl pipecolinate hydrochloride $\mathbf{2 9}$ and proline methyl ester hydrochloride 30 (Fig. 4) as catalysts within the standard Diels-Alder reaction (Table 2; entries 9 and 10) showed the five-membered ring heterocycle 30 to be significantly better (entry $10 ; 62 \%$ ) than the sixmembered ring analogue $\mathbf{2 9}$ (entry 9; 3\%).

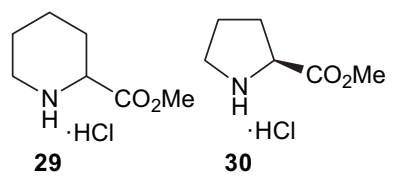

Figure 4. Cyclic catalysts without an $\alpha$-heteroatom.

In the design of any chiral catalyst these important findings on reactivity should be taken into account: Catalysts that do not contain an $\alpha$-heteroatom should be based upon a five-membered ring, catalysts that have an $\alpha$-heteroatom should be based on a sixmembered ring.

In order to try and rationalise these results we carried out a series of computational studies to examine the effects of an $\alpha$-heteroatom. In recent studies, ${ }^{5,8}$ we found that two parameters drawn from density functional theory (DFT) methods could be used to gain insight into the formation and reactivity of iminium ions. Firstly, proton affinity (PA) is related to the barrier to formation of iminium ions, since the key step in this process under acidic reaction conditions is the transfer of a proton from catalyst to substrate. Secondly, the energy of the lowest unoccupied molecular orbital of the iminium ion $\left(E_{\text {LUMO }}\right)$ can be used to measure activation of the substrate towards Diels-Alder cycloaddition. We therefore calculated these properties for five selected amines, $(\mathbf{2}, \mathbf{1 5}, \mathbf{2 6}, \mathbf{2 9}$, and 30) along with their iminium ion derivatives (Table 3 ).

Table 3

Calculated properties of amines and derived iminium ions (B3LYP/6-31+G(d,p))

\begin{tabular}{llll}
\hline Entry & Amine & PA $\left(\mathrm{kJ} \mathrm{mol}^{-1}\right)$ & $E_{\text {LUMO }}(\mathrm{eV})$ \\
\hline 1 & $\mathbf{2}$ & 913.6 & -6.41 \\
2 & $\mathbf{1 5}$ & 911.9 & -6.20 \\
3 & $\mathbf{2 6}$ & 917.3 & -6.38 \\
4 & $\mathbf{2 9}$ & 957.1 & -6.35 \\
5 & $\mathbf{3 0}$ & 958.8 & -6.35 \\
\hline
\end{tabular}

From this data it can be concluded that introduction of an $\alpha$ heteroatom on a cyclic framework significantly lowers the proton affinity of the basic nitrogen. This is the case for both five-membered (entry 2; $911.9 \mathrm{~kJ} \mathrm{~mol}^{-1}$ vs entry $5 ; 958.8 \mathrm{~kJ} \mathrm{~mol}^{-1}$ ) and sixmembered rings (entry $3 ; 917.3 \mathrm{~kJ} \mathrm{~mol}^{-1}$ vs entry $4 ; 957.1 \mathrm{~kJ} \mathrm{~mol}^{-1}$ ). In the five-membered ring series introduction of the $\alpha$-heteroatom substantially increases the energy level of the LUMO (entry 2; $-6.2 \mathrm{eV}$ vs entry $5 ;-6.35 \mathrm{eV}$ ) whereas in the six-membered ring series the energy level of the LUMO decreases (entry $3 ;-6.38 \mathrm{eV}$ vs entry $4 ;-6.35 \mathrm{eV}$ ). This trend in $\mathrm{E}_{\mathrm{LUMO}}$ is reflected within the reactivity observed with the two series of catalysts where activity is reduced on introduction of an $\alpha$-heteroatom in the five-membered ring scaffold but increased in the six-membered ring series. Recent work on the iminium ion catalysed Diels-Alder reaction has shown the cycloaddition step to be rate determining. ${ }^{8,9}$ It is therefore possible that $E_{\text {LUMO }}$ can be adopted as a simple means for the computational evaluation of catalyst activity prior to synthesis. It is important to note these computational results do not explain the marked difference in reactivity of proline methyl ester hydrochloride (30) and methyl pipecolinate hydrochloride (29) and further investigations are clearly needed in order to develop a robust predictive model for the reactivity of secondary amines in iminium ion catalysed transformations. 


\section{Conclusions}

In summary, we have explored the use of five- and six-membered cyclic hydrazides as novel molecular scaffolds for use in the iminium ion catalysed Diels-Alder reaction. The five-membered heterocycles performed poorly as catalysts whereas their sixmembered counterparts provide an excellent basis for catalyst design. These findings are in stark contrast to catalyst scaffolds that do not bear an $\alpha$-heteroatom, where five-membered cyclic secondary amines deliver significantly improved activity when compared to six-membered rings. These results provide a strong basis with which to design novel, state-of-the-art chiral scaffolds that could have applicability in catalytic asymmetric iminium ion catalysed cycloaddition and conjugate addition reactions. ${ }^{10}$ Additionally, the catalysts described may also find applicability in the Asymmetric Counteranion-Directed Catalysis $(A C D C)^{11}$ technology recently disclosed by List where an achiral secondary amine can be coupled with a chiral anion in iminium ion activated processes. Our work in these areas will be described in due course.

\section{Experimental}

\subsection{General}

All ${ }^{1} \mathrm{H}$ and ${ }^{13} \mathrm{C}$ nuclear magnetic resonance spectra were recorded on a Bruker DPX-400, Bruker Avance 500 or Bruker DPX-250 spectrometer, with ${ }^{13} \mathrm{C}$ spectra being recorded at 100,125 or $62.5 \mathrm{MHz}$. Mass spectra were obtained using a Fisons VG platform II spectrometer. High resolution mass spectra were obtained by the EPSRC mass spectrometry service, Swansea. Melting points were determined on a Khofler Hot Stage Micro Melting Point Apparatus. Infrared spectra were recorded in the range $4000-600 \mathrm{~cm}^{-1}$ using a Perkin-Elmer 1600 series spectrophotometer as thin films or as Nujol mulls. Thin Layer Chromatography (TLC) was performed on Merck 5554 60F silica gel coated aluminium plates and detection was effected with a solution of $10 \%$ ceric sulfate in $10 \%$ sulfuric acid, followed by heating the plates. Purification of compounds was achieved by medium pressure chromatography using Merck 9385 60 silica gel.

All DFT calculations were carried out using the Gaussian03 package, ${ }^{12}$ at the B3LYP/6-31+G(d,p) level. ${ }^{13,14}$ ELUMo was calculated with this method directly, while PA included an unscaled zero-point vibrational energy (ZPVE) correction from harmonic frequency calculation at the same level.

\subsection{Isoxazolidine hydrochloride $6^{6}$}

tert-Butyl $N$-hydroxycarbamate $10(2.00 \mathrm{~g}, 15.0 \mathrm{mmol})$ was stirred in a solution of toluene $(20 \mathrm{~mL})$, sodium hydroxide $(10 \mathrm{~mL}$, $50 \% \mathrm{w} / \mathrm{w}$ ) and tetraethylammonium bromide ( $453 \mathrm{mg}, 2.16 \mathrm{mmol}$ ). 1,3-Dibromopropane ( $4.71 \mathrm{~g}, 22.5 \mathrm{mmol}, 2.37 \mathrm{~mL}$ ) was added to the slurry, which was subsequently brought to reflux for $90 \mathrm{~min}$. Ethyl acetate $(15 \mathrm{~mL})$ was added and the mixture, which was washed with saturated sodium hydrogen carbonate solution $(20 \mathrm{~mL})$, water $(15 \mathrm{~mL})$, and brine $(15 \mathrm{~mL})$. The organic phase was separated, dried $\left(\mathrm{MgSO}_{4}\right)$ and the solvent removed under reduced pressure. The crude product was purified by chromatography eluting with acetone in light petrol (1:9) to give tert-butyl isoxazolidine-2-carboxylate $12(441 \mathrm{mg}, 17 \%)$ as a clear colourless oil; $\nu_{\max }(\mathrm{Nujol}) / \mathrm{cm}^{-1}$ $2979,1734,1709 ; \delta_{\mathrm{H}}\left(400 \mathrm{MHz}, \mathrm{CDCl}_{3}\right) 3.84\left(2 \mathrm{H}, \mathrm{t}, J 7.2, \mathrm{CH}_{2} \mathrm{CH}_{2} \mathrm{ON}\right)$, $3.55\left(2 \mathrm{H}, \mathrm{t}, J 7.2, \mathrm{CH}_{2} \mathrm{~N}\right), 2.16\left(2 \mathrm{H}\right.$, quin, $J$ 7.2, $\left.\mathrm{CH}_{2} \mathrm{CH}_{2} \mathrm{~N}\right), 1.43(9 \mathrm{H}, \mathrm{s}$, $\left.\mathrm{CH}_{3}\right) ; \delta_{\mathrm{C}}\left(100 \mathrm{MHz}, \mathrm{CDCl}_{3}\right) \delta_{\mathrm{C}} 159.7(\mathrm{C}), 81.8(\mathrm{C}), 68.4\left(\mathrm{CH}_{2}\right), 46.8$ $\left(\mathrm{CH}_{2}\right), 28.2\left(\mathrm{CH}_{3}\right), 27.9\left(\mathrm{CH}_{2}\right) ; m / z(\mathrm{APCI}): 174.7\left(\mathrm{M}+\mathrm{H}^{+}, 8 \%\right), 118.7$ (100); HRMS (ES): found $\mathrm{M}+\mathrm{H}^{+}, 174.1128 . \mathrm{C}_{8} \mathrm{H}_{16} \mathrm{NO}_{3}$ requires, 174.1125 .
tert-Butyl isoxazolidine-2-carboxylate $12(112 \mathrm{mg}, 0.65 \mathrm{mmol})$ was dissolved in dry ether $(0.5 \mathrm{~mL})$. Hydrochloric acid in ether $(2 \mathrm{M}$, $3.24 \mathrm{mmol}, 1.62 \mathrm{~mL}$ ) was added and the resulting solution allowed to stand until reaction was complete by TLC. The volume of liquor was reduced in vacuo and the precipitate was filtered and washed with cold ether affording the title compound $\mathbf{6}$ as a colourless solid (63 mg, 89\%); $\mathrm{mp}$ (ether/chloroform) $111-112{ }^{\circ} \mathrm{C} ; \nu_{\max }(\mathrm{Nujol}) / \mathrm{cm}^{-1}$ 3386, 2923, 2853, 1459, 1377, 1003; $\delta_{\mathrm{H}}\left(400 \mathrm{MHz}, d_{6}\right.$-DMSO) 12.48 $\left(2 \mathrm{H}\right.$, br s, $\left.\mathrm{NH}_{2}\right), 4.19\left(2 \mathrm{H}, \mathrm{t}, J 7.1, \mathrm{CH}_{2} \mathrm{O}\right), 3.49\left(2 \mathrm{H}, \mathrm{t}, J \mathrm{~J} .1, \mathrm{CH}_{2} \mathrm{~N}\right), 2.41$ $\left(2 \mathrm{H}\right.$, quin, $\left.J 7.1, \mathrm{CH}_{2} \mathrm{CH}_{2} \mathrm{~N}\right) ; \delta_{\mathrm{C}}\left(125 \mathrm{MHz}, d_{6}\right.$-DMSO) $\delta_{\mathrm{C}} 70.9\left(\mathrm{CH}_{2}\right)$, $45.5\left(\mathrm{CH}_{2}\right), 27.9\left(\mathrm{CH}_{2}\right)$.

\subsection{Pyrazolidine hydrochloride 7}

Di-tert-butyl hydrazodiformate $\mathbf{1 1}(5.00 \mathrm{~g}, 21.5 \mathrm{mmol})$ was stirred in a solution of toluene $(50 \mathrm{~mL})$, sodium hydroxide $(25 \mathrm{~mL}, 50 \%$ $\mathrm{w} / \mathrm{w})$ and tetraethylammonium bromide (650 $\mathrm{mg}, 3.10 \mathrm{mmol}) .1,3-$ Dibromopropane $(6.50 \mathrm{~g}, 32.3 \mathrm{mmol}, 3.27 \mathrm{~mL})$ was added and the reaction was brought to reflux for $90 \mathrm{~min}$. Ethyl acetate $(50 \mathrm{~mL})$ was added and the mixture was washed with saturated sodium hydrogen carbonate $(70 \mathrm{~mL})$, water $(50 \mathrm{~mL})$ and brine $(30 \mathrm{~mL})$. The organic phase was separated, dried $\left(\mathrm{MgSO}_{4}\right)$ and the solvent was removed under reduced pressure. The crude product was purified by chromatography eluting with acetone/light petrol (1:9) to give di-tert-butyl pyrazolidine-1,2-dicarboxylate $13(4.33 \mathrm{~g}, 74 \%)$ as a clear colourless oil; $\nu_{\max }(\mathrm{Nujol}) / \mathrm{cm}^{-1} 2928,2853,1704,1489$, 1422,$1156 ; \delta_{\mathrm{H}}\left(400 \mathrm{MHz}, \mathrm{CDCl}_{3}\right) 3.79-3.86(2 \mathrm{H}, \mathrm{m}, \mathrm{CHHN}), 3.11-$ $3.19(2 \mathrm{H}, \mathrm{m}, \mathrm{CHHN}), 1.91-1.98\left(2 \mathrm{H}, \mathrm{m}, \mathrm{CH}_{2} \mathrm{CH}_{2} \mathrm{~N}\right), 1.41\left(18 \mathrm{H}, \mathrm{s}, \mathrm{CH}_{3}\right)$; $\delta_{\mathrm{C}}\left(100 \mathrm{MHz}, \mathrm{CDCl}_{3}\right) \delta_{\mathrm{C}} 156.1(\mathrm{C}), 81.1(\mathrm{C}), 46.3\left(\mathrm{CH}_{2}\right), 28.2\left(\mathrm{CH}_{3}\right)$, $25.7\left(\mathrm{CH}_{2}\right) ; \mathrm{m} / \mathrm{z}$ (APCI): $273.7\left(\mathrm{M}+\mathrm{H}^{+}, 10 \%\right), 217.7(10), 117.8(100)$; HRMS (ES): found $\mathrm{M}+\mathrm{H}^{+}, 273.1812 . \mathrm{C}_{13} \mathrm{H}_{25} \mathrm{~N}_{2} \mathrm{O}_{4}$ requires, 273.1809 .

Di-tert-butyl pyrazolidine-1,2-dicarboxylate 13 (200 mg, $0.73 \mathrm{mmol}$ ) was dissolved in dry ether $(0.5 \mathrm{~mL})$. Hydrochloric acid in ether ( $2 \mathrm{M}, 1.85 \mathrm{~mL}, 3.67 \mathrm{mmol})$ was added and the resulting solution was left to stand until reaction was complete by TLC. The volume of liquor was reduced and the precipitate was filtered and washed with cold ether resulting in the title compound 7 as a colourless solid (95 mg, 96\%); mp (ether/chloroform) $77-78^{\circ} \mathrm{C}$ [lit. ${ }^{6}$ $\left.\operatorname{mp~54-56~}{ }^{\circ} \mathrm{C}\right] ; \nu_{\max }(\mathrm{Nujol}) / \mathrm{cm}^{-1} 3395,2922,2852,1461,1377 ; \delta_{\mathrm{H}}$ $\left(400 \mathrm{MHz}, d_{6}\right.$-DMSO) $8.89\left(3 \mathrm{H}, \mathrm{br} \mathrm{s}, \mathrm{NH}_{2}\right), 3.12\left(4 \mathrm{H}, \mathrm{t}, J 7.2, \mathrm{CH}_{2} \mathrm{~N}\right)$, $2.04\left(2 \mathrm{H}\right.$, quin, $J$ 7.2, $\left.\mathrm{CH}_{2} \mathrm{CH}_{2} \mathrm{~N}\right) ; \delta_{\mathrm{C}}\left(100 \mathrm{MHz}, d_{6}\right.$-DMSO $) 45.8\left(\mathrm{CH}_{2}\right)$, $25.4\left(\mathrm{CH}_{2}\right) . \mathrm{m} / \mathrm{z}(\mathrm{APCl}): 73.1\left(\mathrm{M}+\mathrm{H}^{+}, 100 \%\right)$; HRMS (ES): found $\mathrm{M}-\mathrm{Cl}^{+}$, 73.0773. $\mathrm{C}_{3} \mathrm{H}_{9} \mathrm{~N}_{2}$ requires, 73.0766.

\subsection{Ethyl pyrazolidine-1-carboxylate hydrochloride 15}

Di-tert-butyl dicarbonate $(10.50 \mathrm{~g}, 48 \mathrm{mmol})$, in THF $(90 \mathrm{~mL})$, was cooled to $0^{\circ} \mathrm{C}$. Ethyl carbazate $14(5.00 \mathrm{~g}, 48 \mathrm{mmol})$ was added. The resulting solution was stirred at $0{ }^{\circ} \mathrm{C}$ for $30 \mathrm{~min}$ and then allowed to warm to room temperature for a further $24 \mathrm{~h}$. Removal of the solvent under reduced pressure afforded $N^{\prime}$-tert-butyl ester ethyl carbazate $(9.40 \mathrm{~g}, 96 \%)$ as a white amorphous solid with no further purification required; $\mathrm{mp}$ (THF) $98-99{ }^{\circ} \mathrm{C}$ [lit. ${ }^{15} \mathrm{mp} 92-$ $\left.93^{\circ} \mathrm{C}\right] ; \quad \nu_{\max }(\mathrm{Nujol}) / \mathrm{cm}^{-1} 3282,2926,2852,1740,1712 ; \delta_{\mathrm{H}}$ $\left(400 \mathrm{MHz}, \mathrm{CDCl}_{3}\right) 6.54(1 \mathrm{H}, \mathrm{br} \mathrm{s}, \mathrm{NH}), 6.39(1 \mathrm{H}, \mathrm{br} \mathrm{s}, \mathrm{NH}), 3.95(2 \mathrm{H}, \mathrm{q}$, J 7.1, $\left.\mathrm{CH}_{2}\right), 1.36\left(9 \mathrm{H}, \mathrm{s}, \mathrm{C}\left(\mathrm{CH}_{3}\right)_{3}\right), 1.20\left(3 \mathrm{H}, \mathrm{t}, J \mathrm{7.1}, \mathrm{CH}_{2} \mathrm{CH}_{3}\right) ; \delta_{\mathrm{C}}$ $\left(100 \mathrm{MHz}, \mathrm{CDCl}_{3}\right) 156.9(\mathrm{C}), 155.8(\mathrm{C}), 81.7(\mathrm{C}), 62.1\left(\mathrm{CH}_{2}\right), 28.1$ $\left(\mathrm{CH}_{3}\right), 14.4\left(\mathrm{CH}_{3}\right) ; \mathrm{m} / z$ (APCI): $205\left(\mathrm{M}+\mathrm{H}^{+}, 10 \%\right), 149$ (100); HRMS (ES): found $\mathrm{M}+\mathrm{H}^{+}$, 205.1183. $\mathrm{C}_{8} \mathrm{H}_{17} \mathrm{~N}_{2} \mathrm{O}_{4}$ requires, 205.1183.

$N^{\prime}$-tert-Butyl ester ethyl carbazate $(2.00 \mathrm{~g}, 9.8 \mathrm{mmol})$ was stirred in a solution of toluene $(20 \mathrm{~mL})$, sodium hydroxide $(10 \mathrm{~mL}, 50 \% \mathrm{w} /$ $\mathrm{w})$, and tetraethylammonium bromide $(290 \mathrm{mg}, 1.24 \mathrm{mmol}) .1,3-$ Dibromopropane $(3.07 \mathrm{~g}, 14.7 \mathrm{mmol}, 1.55 \mathrm{~mL}$ ) was added to the slurry, which was subsequently brought to reflux for $90 \mathrm{~min}$. Ethyl acetate $(15 \mathrm{~mL})$ was added and the mixture, which was washed with saturated sodium hydrogen carbonate solution $(20 \mathrm{~mL})$, water 
(15 mL) and brine $(15 \mathrm{~mL})$. The organic phase was separated, dried $\left(\mathrm{MgSO}_{4}\right)$ and the solvent removed under reduced pressure. The crude reaction mixture was purified by chromatography eluting with acetone/light petrol (1:9) resulting in tert-butyl ethyl pyrazolidine-1,2-dicarboxylate $(1.94 \mathrm{~g}, 81 \%)$ as a clear colourless oil; $\nu_{\max }(\mathrm{Nujol}) / \mathrm{cm}^{-1} 2979,1730,1700,1484,1453,1426,1108 ; \delta_{\mathrm{H}}$ $\left(400 \mathrm{MHz}, \mathrm{CDCl}_{3}\right)$ 4.03-4.22 (2H, m, $\left.\mathrm{CH}_{2} \mathrm{~N}\right), 3.85(2 \mathrm{H}, \mathrm{q}, J$ 7.1, $\left.\mathrm{CH}_{2} \mathrm{CH}_{3}\right), 3.10-3.26\left(2 \mathrm{H}, \mathrm{m}, \mathrm{CH}_{2} \mathrm{~N}\right), 1.98\left(2 \mathrm{H}\right.$, quin, $J$ 7.0, $\left.\mathrm{CH}_{2} \mathrm{CH}_{2} \mathrm{~N}\right)$, $1.42\left(9 \mathrm{H}, \mathrm{s}, \mathrm{CH}_{3}\right), 1.23\left(3 \mathrm{H}, \mathrm{t}, J\right.$ 7.1, $\left.\mathrm{CH}_{2} \mathrm{CH}_{3}\right) ; \delta_{\mathrm{C}}\left(100 \mathrm{MHz}, \mathrm{CDCl}_{3}\right)$ $160.4(\mathrm{C}), 158.2(\mathrm{C}), 82.1(\mathrm{C}), 59.7\left(\mathrm{CH}_{2}\right), 51.2\left(\mathrm{CH}_{2}\right), 51.9\left(\mathrm{CH}_{2}\right), 34.1$ $\left(\mathrm{CH}_{2}\right), 29.7\left(\mathrm{CH}_{3}\right), 14.2\left(\mathrm{CH}_{3}\right) ; \mathrm{m} / z(\mathrm{APCI}): 245.7\left(\mathrm{M}+\mathrm{H}^{+}, 16 \%\right), 189.6$ (100), 145.6 (71); HRMS (ES): found $\mathrm{M}+\mathrm{NH}_{4}^{+}, 262.1759 . \mathrm{C}_{11} \mathrm{H}_{24} \mathrm{~N}_{3} \mathrm{O}_{4}$ requires, 262.1761 .

tert-Butyl ethyl pyrazolidine-1,2-dicarboxylate (100 mg, $0.40 \mathrm{mmol})$ was dissolved in dry ether $(0.5 \mathrm{~mL})$. Hydrochloric acid in ether $(2 \mathrm{M}, 1.0 \mathrm{~mL}, 2.00 \mathrm{mmol})$ was added and the reaction left to stand until complete by TLC. The volume of ether was reduced and the precipitate was filtered and washed with cold ether. The solvent was removed under reduced pressure resulting in the title compound 15 as a colourless solid ( $74 \mathrm{mg}, 87 \%$ ); mp (ether/chloroform) 129$130^{\circ} \mathrm{C} ; \nu_{\max }(\mathrm{Nujol}) / \mathrm{cm}^{-1} 2921,1712,1460,1377,1300,1215,1157$, $1122,1090,1032 ; \delta_{\mathrm{H}}\left(400 \mathrm{MHz}, \mathrm{CD}_{3} \mathrm{OD}\right) 4.30\left(2 \mathrm{H}, \mathrm{q}, J 7.1, \mathrm{CH}_{2} \mathrm{CH}_{3}\right), 3.74$ $\left(2 \mathrm{H}, \mathrm{t}, J 7.0, \mathrm{CH}_{2} \mathrm{~N}\right), 3.60\left(2 \mathrm{H}, \mathrm{t}, J 7.0, \mathrm{CH}_{2} \mathrm{~N}\right), 2.37(2 \mathrm{H}$, quin, $J$ 7.0, $\left.\mathrm{CH}_{2} \mathrm{CH}_{2} \mathrm{~N}\right), 1.34\left(3 \mathrm{H}, \mathrm{t}, J\right.$ 7.1, $\left.\mathrm{CH}_{2} \mathrm{CH}_{3}\right) ; \delta_{\mathrm{C}}\left(100 \mathrm{MHz}, \mathrm{CDCl}_{3}\right) 153.8(\mathrm{C})$, 63.8 $\left(\mathrm{CH}_{2}\right), 46.3\left(\mathrm{CH}_{2}\right), 45.4\left(\mathrm{CH}_{2}\right), 24.4\left(\mathrm{CH}_{2}\right), 14.4\left(\mathrm{CH}_{3}\right) ; \mathrm{m} / \mathrm{z}(\mathrm{ES}): 145$ $\left(\mathrm{M}-\mathrm{Cl}^{+}, 100 \%\right), 116.9$ (43); HRMS (ES): found $\mathrm{M}-\mathrm{Cl}^{+}, 145.0973$. $\mathrm{C}_{6} \mathrm{H}_{13} \mathrm{~N}_{2} \mathrm{O}_{2}$ requires, 145.0972 .

\subsection{Benzyl pyrazolidine-1-carboxylate hydrochloride 17}

Benzylchloroformate (5.69 g, $33.4 \mathrm{mmol}, 4.80 \mathrm{~mL}$ ) was added to a vigorously stirred solution of tert-butyl carbazate $\mathbf{1 6}(4.41 \mathrm{~g}$, $33.4 \mathrm{mmol})$, in a biphasic solution of chloroform $(62 \mathrm{~mL})$ and aqueous sodium hydroxide $(1.8 \mathrm{M}, 1.49 \mathrm{~g}, 37 \mathrm{mmol}, 21 \mathrm{~mL})$. The resulting solution was stirred at room temperature for $24 \mathrm{~h}$. The organic layer was separated and washed with water $(10 \mathrm{~mL})$ and a citric acid solution $(10 \mathrm{~mL}, 10 \% \mathrm{w} / \mathrm{w})$. The resultant liquor was dried $\left(\mathrm{MgSO}_{4}\right)$ and the solvent was removed to give $N^{\prime}$-tert-butyl ester benzyl carbazate $(8.08 \mathrm{~g}, 91 \%)$ as a white solid with no further purification required; $\mathrm{mp}$ (chloroform/light petrol) $71-73{ }^{\circ} \mathrm{C}$ [lit. ${ }^{6}$ $\left.\mathrm{mp} 79-80^{\circ} \mathrm{C}\right] ; \nu_{\max }(\mathrm{Nujol}) / \mathrm{cm}^{-1} 3268,2924,1755,1703,1515,1463$, 1377; $\delta_{\mathrm{H}}\left(400 \mathrm{MHz}, \mathrm{CDCl}_{3}\right) 7.26(5 \mathrm{H}$, br s, Ar- $H), 6.76(1 \mathrm{H}$, br s, NH), $6.45(1 \mathrm{H}$, br s, $\mathrm{NH}), 5.07\left(2 \mathrm{H}, \mathrm{s}, \mathrm{CH}_{2}\right), 1.38\left(9 \mathrm{H}, \mathrm{s}, \mathrm{CH}_{3}\right) ; \delta_{\mathrm{C}}(100 \mathrm{MHz}$, $\left.\mathrm{CDCl}_{3}\right) 156.7(\mathrm{C}), 155.7$ (C), $135.6(\mathrm{C}), 128.5(\mathrm{CH}), 128.4(\mathrm{CH})$, 128.3 $(\mathrm{CH}), 81.9(\mathrm{C}), 67.8\left(\mathrm{CH}_{2}\right), 28.1\left(\mathrm{CH}_{3}\right) ; \mathrm{m} / \mathrm{z}(\mathrm{APCI}): 167.5(\mathrm{M}+\mathrm{H}-$ $\left.\mathrm{Boc}^{+}, 46 \%\right), 91.8$ (100); HRMS (ES): found $\mathrm{M}+\mathrm{H}^{+}, 267.1268$. $\mathrm{C}_{13} \mathrm{H}_{19} \mathrm{~N}_{2} \mathrm{O}_{4}$ requires, 267.1267.

$N^{\prime}$-tert-Butyl ester benzyl carbazate $(5.00 \mathrm{~g}, 18.8 \mathrm{mmol})$ was stirred in a solution of toluene $(50 \mathrm{~mL})$, sodium hydroxide $(25 \mathrm{~mL}$, $50 \% \mathrm{w} / \mathrm{w})$, and tetraethylammonium bromide ( $650 \mathrm{mg}, 3.10 \mathrm{mmol}$ ). 1,3-Dibromopropane (5.69 g, $28.2 \mathrm{mmol}, 2.90 \mathrm{~mL}$ ) was added and the solution was brought to reflux for $80 \mathrm{~min}$. Ethyl acetate $(50 \mathrm{~mL})$ was added and the mixture was subsequently washed with saturated sodium hydrogen carbonate solution $(70 \mathrm{~mL})$, water $(50 \mathrm{~mL})$, and brine $(30 \mathrm{~mL})$. The organic phase was separated, dried $\left(\mathrm{MgSO}_{4}\right)$, and the solvent removed under reduced pressure. The reaction mixture was purified by chromatography eluting with acetone/light petrol (1:9), which resulted in tert-butyl benzyl pyrazolidine-1,2dicarboxylate $\left(4.54 \mathrm{~g}, 79 \%\right.$ ) as a clear colourless oil; $\nu_{\max }$ (Nujol)/ $\mathrm{cm}^{-1} 2933,1710,1459,1379,1087 ; \delta_{\mathrm{H}}\left(500 \mathrm{MHz}, \mathrm{CDCl}_{3}\right) 7.25-7.38$ (5H, m, Ar- $H$ ), 5.10-5.28 (2H, m, OCH $\mathrm{OCr}_{2}$, 3.87-3.96 (2H, m, CHHN), 3.16-3.35 (2H, m, CHHN), 1.98-2.08 (2H, m, $\left.\mathrm{CH}_{2} \mathrm{CH}_{2} \mathrm{~N}\right), 1.37(9 \mathrm{H}, \mathrm{s}$, $\left.\mathrm{CH}_{3}\right) ; \delta_{\mathrm{C}}\left(60 \mathrm{MHz}, \mathrm{CDCl}_{3}\right) 156.8(\mathrm{C}), 156.3(\mathrm{C}), 136.2(\mathrm{C}), 128.5(\mathrm{CH})$, $127.9(\mathrm{CH}), 127.0(\mathrm{CH}), 81.6(\mathrm{C}), 67.8\left(\mathrm{CH}_{2}\right), 46.7\left(\mathrm{CH}_{2}\right), 46.3\left(\mathrm{CH}_{2}\right)$, $28.1\left(\mathrm{CH}_{3}\right), 25.7\left(\mathrm{CH}_{2}\right) ; \mathrm{m} / z$ (APCI): $307.3\left(\mathrm{M}+\mathrm{H}^{+}, 100 \%\right)$; HRMS (ES): found $\mathrm{M}+\mathrm{H}^{+}$, 307.164. $\mathrm{C}_{16} \mathrm{H}_{23} \mathrm{~N}_{2} \mathrm{O}_{4}$ requires, 307.1652.
tert-Butyl benzyl pyrazolidine-1,2-dicarboxylate (100 mg, $0.33 \mathrm{mmol}$ ) was dissolved in dry ether $(0.5 \mathrm{~mL})$. Hydrochloric acid in ether $(2 \mathrm{M}, 0.85 \mathrm{~mL}, 1.65 \mathrm{mmol})$ was added and the reaction left to stand until complete by TLC. The volume of ether was reduced and the precipitate was filtered and washed with cold ether. The solvent was removed under reduced pressure resulting in the title compound 17 as a colourless solid (74 mg, 94\%); mp (ether/chloroform) 150$151^{\circ} \mathrm{C} ; \nu_{\max }(\mathrm{Nujol}) / \mathrm{cm}^{-1} 2927,2854,1721 ; \delta_{\mathrm{H}}\left(400 \mathrm{MHz}, \mathrm{CDCl}_{3}\right)$ 7.30-7.51 (5H, m, Ar-H), $5.22\left(2 \mathrm{H}, \mathrm{s}, \mathrm{CH}_{2} \mathrm{Ar}\right), 3.64\left(2 \mathrm{H}, \mathrm{t}, J 6.9, \mathrm{CH}_{2} \mathrm{~N}\right)$, $3.42\left(2 \mathrm{H}, \mathrm{t}, J 6.9, \mathrm{CH}_{2} \mathrm{~N}\right), 2.51\left(2 \mathrm{H}\right.$, br s, $\left.\mathrm{NH}_{2}\right), 2.20(2 \mathrm{H}$, quin, $J 6.9$, $\left.\mathrm{CH}_{2} \mathrm{CH}_{2} \mathrm{~N}\right) ; \delta_{\mathrm{C}}\left(125 \mathrm{MHz}, d_{6}\right.$-DMSO) $154.7(\mathrm{C}), 136.0(\mathrm{C}), 128.9(\mathrm{CH})$, 128.7 (CH), 128.4 (CH), $68.3\left(\mathrm{CH}_{2}\right), 46.6\left(\mathrm{CH}_{2}\right), 46.4\left(\mathrm{CH}_{2}\right), 24.6\left(\mathrm{CH}_{2}\right)$; $\mathrm{m} / \mathrm{z}$ (APCI): $207.7\left(\mathrm{M}-\mathrm{Cl}^{+}, 81 \%\right)$; HRMS (ES): found $\mathrm{M}-\mathrm{Cl}^{+}, 207.1126$. $\mathrm{C}_{11} \mathrm{H}_{15} \mathrm{~N}_{2} \mathrm{O}_{2}$ requires, 207.1128.

\subsection{Experimental procedure for catalytic runs}

trans-Cinnamaldehyde 22 ( $252 \mathrm{mg}, 1.9 \mathrm{mmol}, 0.24 \mathrm{~mL}, 1.0$ equiv) was added to a solution of catalyst ( $10 \mathrm{~mol} \%, 0.19 \mathrm{mmol}$ ) in methanol $(2.0 \mathrm{~mL})$ at $25^{\circ} \mathrm{C}$ and the resulting mixture was stirred for $5 \mathrm{~min}$ to initiate iminium ion formation. Freshly cracked cyclopentadiene 21 (323 mg, $4.9 \mathrm{mmol}, 0.38 \mathrm{~mL}, 2.5$ equiv) was added in a single aliquot and stirring was continued for a known time. The solvent was removed under reduced pressure and the residue was hydrolysed in a chloroform $(2 \mathrm{~mL})$, water $(1 \mathrm{~mL})$ trifluoroacetic acid $(1 \mathrm{~mL})$ mixture over night. Saturated sodium hydrogen carbonate solution $(18 \mathrm{~mL})$ was added to neutralise the solution and the aqueous phase was extracted with dichloromethane $(2 \times 20 \mathrm{~mL})$. The combined organic phase was washed with water $(10 \mathrm{~mL})$ and $\operatorname{dried}\left(\mathrm{Na}_{2} \mathrm{SO}_{4}\right)$ prior to the removal of the volatiles under reduced pressure. ${ }^{1} \mathrm{H}$ NMR spectroscopy of the crude reaction mixture was used to establish the conversion to the products and exo:endo ratios through the integration of aldehyde peaks at: $\delta_{\mathrm{H}}\left(400 \mathrm{MHz}, \mathrm{CDCl}_{3}\right) 9.8$ (exo) 9.65 (cinnamaldehyde) 9.53 (endo). The products were then purified by flash column chromatography eluting with ethyl acetate/light petroleum (1:9) resulting in a mixture of the exo- and endo- isomers of 3-phenylbicyclo[2.2.1 ]hept-5-ene-2-carboxaldehyde $\mathbf{2 3}$ and $\mathbf{2 4}$ as a pale yellow oil. ${ }^{1} \mathrm{H}$ NMR, ${ }^{13} \mathrm{C}$ NMR and IR data were consistent with previously reported literature values; ${ }^{16} \mathrm{u}_{\max }$ (liquid film)/ $\mathrm{cm}^{-1} 1718,1601,1497$; $m / z(E I): ~ 198\left(\mathrm{M}^{+}, 10 \%\right), 132$ (89), 131 (100), 103 (52), 77 (21), 66 (54); exo- $23 \delta_{\mathrm{H}}\left(400 \mathrm{MHz}, \mathrm{CDCl}_{3}\right) 9.85(1 \mathrm{H}, \mathrm{d}, J 2.02, \mathrm{CHO}), 7.4-7.0(5 \mathrm{H}, \mathrm{m}$, $\mathrm{Ar} H), 6.27(1 \mathrm{H}, \mathrm{dd}, J 5.6$ and 3.6, $\mathrm{CH}=\mathrm{CH}), 6.01(1 \mathrm{H}$, dd, $J 5.6$ and 3.6, $\mathrm{CH}=\mathrm{CH}), 3.66(1 \mathrm{H}, \mathrm{dd}, \mathrm{J} 5.0$ and $3.4, \mathrm{CHPh}), 3.25-3.05\left(2 \mathrm{H}, \mathrm{m}, \mathrm{CHCH}_{2}\right)$, 2.55-2.45 (1H, m, CHCHO), 1.65-1.45 $\left(2 \mathrm{H}, \mathrm{m}, \mathrm{CH}_{2}\right)$; endo- $24 \delta_{\mathrm{H}}$ $\left(400 \mathrm{MHz}, \mathrm{CDCl}_{3}\right) 9.53(1 \mathrm{H}, \mathrm{d}, \mathrm{J} 2.2, \mathrm{CHO}), 7.4-7.0(5 \mathrm{H}, \mathrm{m}, \mathrm{ArH}), 6.36$ $(1 \mathrm{H}, \mathrm{dd}, J 5.6$ and 3.6, $\mathrm{CH}=\mathrm{CH}), 6.10(1 \mathrm{H}, \mathrm{dd}, J 5.6$ and 3.6, $\mathrm{CH}=\mathrm{CH})$, 3.3-3.2 (1H, m, CHPh), 3.1-3.05 $\left(1 \mathrm{H}, \mathrm{m}, \mathrm{CHCH}_{2}\right), 3.04-3.0(1 \mathrm{H}, \mathrm{m}$, $\left.\mathrm{CHCH}_{2}\right), 2.94-2.86$ (1H, m, CHCHO), $1.85-1.66\left(2 \mathrm{H}, \mathrm{m}, \mathrm{CH}_{2}\right)$.

\section{7. tert-Butyl ethyl piperazine-1,2-dicarboxylate hydrochloride 26}

$N^{\prime}$-tert-Butyl ester ethyl carbazate $(2.00 \mathrm{~g}, 9.80 \mathrm{mmol})$ was added to a stirred solution of toluene $(40 \mathrm{~mL})$ containing tetraethylammonium bromide ( $230 \mathrm{mg}, 1.63 \mathrm{mmol}$ ) and 1,4-dibromobutane $(3.17 \mathrm{~g}, 14.7 \mathrm{mmol}, 1.75 \mathrm{~mL})$. Aqueous sodium hydroxide $(20 \mathrm{~mL}, 50 \% \mathrm{w} / \mathrm{w})$ was added at ambient temperate and the reaction brought to reflux for $45 \mathrm{~min}$ or until the $N^{\prime}$-tert-butyl ester ethyl carbazate was consumed. The reaction was cooled and diluted with ethyl acetate $(50 \mathrm{~mL})$ and washed with aqueous saturated sodium hydrogen carbonate. The organic layer was separated, washed with water $(10 \mathrm{~mL})$ and brine $(10 \mathrm{~mL})$ and subsequently dried $\left(\mathrm{MgSO}_{4}\right)$. The solvent was removed under reduced pressure. The crude mixture was purified by chromatography eluting with ether/light petrol (1:1) affording tert-butyl ethyl piperazine-1,2dicarboxylate $(2.00 \mathrm{~g}, 79 \%)$ as a light yellow oil; $\delta_{\mathrm{H}}\left(400 \mathrm{MHz}, d_{6^{-}}\right.$ 
DMSO $) 4.20-4.10\left(2 \mathrm{H}, \mathrm{m}, \mathrm{OCH}_{2} \mathrm{CH}_{3}\right), 4.10-4.05(2 \mathrm{H}, \mathrm{m}, \mathrm{CHHN}), 2.88$ (2H, m, CHHN), 1.65-1.61 (4H, m, $\left.\mathrm{CH}_{2} \mathrm{CH}_{2} \mathrm{CH}_{2} \mathrm{CH}_{2}\right), 1.46(9 \mathrm{H}, \mathrm{s}$, $\left.\left(\mathrm{CH}_{3}\right)_{3}\right), 1.27\left(3 \mathrm{H}, \mathrm{t}, J \mathrm{~J} .0, \mathrm{CH}_{3}\right) ; \delta_{\mathrm{C}}\left(100 \mathrm{MHz}, \mathrm{CDCl}_{3}\right) 161.2(\mathrm{C}), 159.9$ (C), $80.4(\mathrm{C}), 59.7\left(\mathrm{CH}_{2}\right), 47.2\left(\mathrm{CH}_{2}\right), 46.5\left(\mathrm{CH}_{2}\right), 29.1\left(\mathrm{CH}_{3}\right), 21.7$ $\left(\mathrm{CH}_{2}\right), 14.1\left(\mathrm{CH}_{3}\right) ; \mathrm{m} / \mathrm{z}(\mathrm{ES}): 258.0\left(\mathrm{M}+\mathrm{H}^{+}, 68 \%\right), 231.1(21), 185.0$ (79), 157.0 (100); HRMS (ES): found $\mathrm{M}+\mathrm{H}^{+}, 259.1581 . \mathrm{C}_{12} \mathrm{H}_{23} \mathrm{~N}_{2} \mathrm{O}_{4}$ requires, 259.1580.

tert-Butyl ethyl piperazine-1,2-dicarboxylate (500 mg, $1.97 \mathrm{mmol}$ ) was dissolved in dry ether $(1.0 \mathrm{~mL})$ prior to the addition of hydrochloric acid in ether $(1 \mathrm{M}, 10 \mathrm{~mL})$. The reaction was left to stand at ambient temperature until complete by TLC. The volume of liquor was reduced and the precipitate filtered and washed with cold ether affording the title compound $\mathbf{2 6}$ (294 $\mathrm{mg}, 78 \%$ ) as a colourless solid; $\mathrm{mp}$ $147.5-148^{\circ} \mathrm{C} ; \nu_{\max }(\mathrm{Nujol}) / \mathrm{cm}^{-1} 3460,2962,2253,1734,1560,1468$, 1382,$1261 ; \delta_{\mathrm{H}}\left(400 \mathrm{MHz}, d_{6}\right.$-DMSO $) 4.32\left(2 \mathrm{H}, \mathrm{q}, J 7.1, \mathrm{OCH}_{2} \mathrm{CH}_{3}\right), 3.92$ (2H, t, J 5.6, $\left.\mathrm{CH}_{2} \mathrm{NCO}\right), 3.45\left(2 \mathrm{H}, \mathrm{t}, J 5.8, \mathrm{CH}_{2} \mathrm{NH}_{2}\right), 2.08-2.19(2 \mathrm{H}, \mathrm{m}$, $\mathrm{CH}_{2} \mathrm{CH}_{2} \mathrm{NCO}$ ), $1.69-1.78\left(2 \mathrm{H}, \mathrm{m}, \mathrm{CH}_{2} \mathrm{CH}_{2} \mathrm{NH}_{2}\right), 1.36$ (3H, t, $J$ 7.1, $\left.\mathrm{CH}_{2} \mathrm{CH}_{3}\right) ; \delta_{\mathrm{C}}\left(125 \mathrm{MHz}, d_{6}\right.$-DMSO) $153.2(\mathrm{C}), 62.7\left(\mathrm{CH}_{2}\right), 46.0\left(\mathrm{CH}_{2}\right)$, $45.7\left(\mathrm{CH}_{2}\right), 24.0\left(\mathrm{CH}_{2}\right), 14.6\left(\mathrm{CH}_{2}\right), 14.3\left(\mathrm{CH}_{3}\right) ; \mathrm{m} / \mathrm{z}(\mathrm{ES}): 159.1\left(\mathrm{M}-\mathrm{Cl}^{+}\right.$, 90\%) 131.0 (28), 113.0 (100); HRMS (ES): found $\mathrm{M}+\mathrm{H}^{+}, 159.1129$. $\mathrm{C}_{7} \mathrm{H}_{15} \mathrm{~N}_{2} \mathrm{O}_{2}$ requires, 159.1128 .

\section{8. tert-Butyl benzyl piperazine-1,2-dicarboxylate hydrochloride 28}

tert-Butyl benzyl piperazine-1,2-dicarboxylate was prepared under the standard reaction conditions from $N^{\prime}$-tert-butyl ester benzyl carbazate $27(2.00 \mathrm{~g}, 7.51 \mathrm{mmol})$ and 1,4-dibromobutane $(2.43 \mathrm{~g}, 11.3 \mathrm{mmol}, 1.35 \mathrm{~mL})(1.26 \mathrm{~g}, 52 \%)$ as a colourless solid; $\mathrm{mp}$ 73-74 ${ }^{\circ} \mathrm{C} ; \nu_{\max }$ (Nujol)/ $\mathrm{cm}^{-1} 2928,2855,1712,1683,1453,1425$, $1369,1288,1261,1201,1164,1134,1080,1058 ; \delta_{\mathrm{H}}\left(400 \mathrm{MHz}, d_{6}-\right.$ DMSO) 7.29-7.39 (5H, m, Ar- H), 5.05-5.29 (2H, m, CH $2 \mathrm{Ar}), 4.00-$ $4.22(2 \mathrm{H}, \mathrm{m}, \mathrm{CHHN}), 2.81-3.12(2 \mathrm{H}, \mathrm{m}, \mathrm{CHHN}), 1.54-1.72(4 \mathrm{H}, \mathrm{m}$, $\left.\mathrm{CH}_{2} \mathrm{CH}_{2} \mathrm{CH}_{2} \mathrm{CH}_{2}\right), 1.28-1.54\left(9 \mathrm{H}, \mathrm{m}, \mathrm{C}\left(\mathrm{CH}_{3}\right)_{3}\right) ; \delta_{\mathrm{C}}\left(125 \mathrm{MHz}, \mathrm{CDCl}_{3}\right)$ 154.8 (C), 154.0 (C), 136.4 (C), 128.4 (CH), $128.0(\mathrm{CH}), 127.9(\mathrm{CH}), 81.2$ (C), $67.5\left(\mathrm{CH}_{2}\right), 44.8\left(\mathrm{CH}_{2}\right), 40.4\left(\mathrm{CH}_{2}\right), 28.1\left(\mathrm{CH}_{3}\right), 23.8\left(\mathrm{CH}_{2}\right), 23.6$ $\left(\mathrm{CH}_{2}\right) ; \mathrm{m} / z$ (ES): $343\left(\mathrm{M}+\mathrm{Na}^{+}, 20 \%\right) 265$ (31), 221 (78); HRMS (ES): found $\mathrm{M}+\mathrm{H}^{+}$, 321.1803. $\mathrm{C}_{17} \mathrm{H}_{25} \mathrm{~N}_{2} \mathrm{O}_{4}$ requires, 321.1809.

The hydrochloride salt was prepared under standard conditions (682 $\mathrm{mg}, 85 \%$ ) as a colourless solid; mp (ether/chloroform) 146$147{ }^{\circ} \mathrm{C} ; \nu_{\max }(\mathrm{Nujol}) / \mathrm{cm}^{-1} 3340,2920,1736,1558,1461,1377 ; \delta_{\mathrm{H}}$ (400 MHz, $d_{6}$-DMSO) 11.92 (2H, br s, $\mathrm{NH}_{2}$ ), 7.23-7.39 (5H, m, Ar- $H$ ), $5.52\left(2 \mathrm{H}, \mathrm{s}, \mathrm{CH}_{2} \mathrm{Ar}\right), 3.78-3.86\left(2 \mathrm{H}, \mathrm{m}, \mathrm{CH}_{2} \mathrm{~N}\right), 3.38-3.42(2 \mathrm{H}, \mathrm{m}$, $\left.\mathrm{CH}_{2} \mathrm{~N}\right), 1.95-2.08\left(2 \mathrm{H}, \mathrm{m}, \mathrm{CH}_{2} \mathrm{CH}_{2} \mathrm{CH}_{2} \mathrm{CH}_{2}\right), 1.56-1.65(2 \mathrm{H}, \mathrm{m}$, $\mathrm{CH}_{2} \mathrm{CH}_{2} \mathrm{CH}_{2} \mathrm{CH}_{2}$ ); $\delta_{\mathrm{C}}\left(100 \mathrm{MHz}, d_{6}\right.$-DMSO) 159.1 (C), 141.2 (C), 129.4 $(\mathrm{CH}), 128.1(\mathrm{CH}), 127.4(\mathrm{CH}), 66.8\left(\mathrm{CH}_{2}\right), 52.4\left(\mathrm{CH}_{2}\right), 49.1\left(\mathrm{CH}_{2}\right), 23.4$
$\left(\mathrm{CH}_{2}\right), 20.8\left(\mathrm{CH}_{2}\right) ; \mathrm{m} / z(\mathrm{ES}): 221\left(\mathrm{M}-\mathrm{Cl}^{+}, 100 \%\right)$; HRMS (ES): found $\mathrm{M}-\mathrm{Cl}^{+}$, 221.1285. $\mathrm{C}_{12} \mathrm{H}_{17} \mathrm{~N}_{2} \mathrm{O}_{2}$ requires, 221.1285.

\section{Acknowledgements}

The authors wish to express their gratitude to the EPSRC and GSK for financial support and the EPSRC Mass Spectrometry Service, Swansea for high resolution spectra.

\section{References and notes}

1. Ahrendt, K. A.; Borths, C. J.; MacMillan, D. W. C. J. Am. Chem. Soc. 2000, 122, 4243

2. For a comprehensive review on iminium ion catalysed processes see: Erkkilä, A.; Majander, I.; Pihko, P. M. Chem. Rev. 2007, 107, 5416.

3. For structural investigations into iminium ions derived from imidazolidinones see: (a) Brazier, J. B.; Evans, G.; Gibbs, T. J. K.; Coles, S. J.; Hursthouse, M. B. Platts, J. A.; Tomkinson, N. C. O. Org. Lett. 2009, 11, 133; (b) Grošelj, U. Schweizer, W. B.; Ebert, M.-O.; Seebach, D. Helv. Chim. Acta 2009, 92, 1; (c) Seebach, D.; Grošelj, U.; Badine, D. M.; Schweizer, W. B.; Beck, A. K. Helv. Chim. Acta 2008, 91, 1999.

4. Cavill, J. L.; Peters, J.-E.; Tomkinson, N. C. O. Chem. Commun 2003, 728.

5. (a) Cavill, J. L.; Elliott, R. L.; Evans, G.; Jones, I. L.; Platts, J. A.; Ruda, A. M.; Tomkinson, N. C. O. Tetrahedron 2006, 62, 410; (b) Evans, G. J. S.; White, K. Platts, J. A.; Tomkinson, N. C. O. Org. Biomol. Chem. 2006, 2616.

6. Boros, E. E.; Bouvier, F.; Randhawa, S.; Rabinowitz, M. H. J. Heterocycl. Chem. 2001, 28, 613.

7. (a) Lemay, M.; Ogilive, W. W. Org. Lett. 2005, 7, 4141; Lemay, M.; Ogilive, W. W.J. Org. Chem. 2006, 71, 4663; (b) Lemay, M.; Aumand, L.; Ogilvie, W. W. Adv. Synth. Catal. 2007, 349, 441.

8. Evans, G.; Gibbs, T. J. K.; Jenkins, R. L.; Coles, S. J.; Hursthouse, M. B.; Platts, J. A.; Tomkinson, N. C. O. Angew. Chem., Int. Ed. 2008, 47, 2820.

9. It is important to note that these experiments were conducted in a different solvent and with a different catalyst.

10. Lelais, G.; MacMillan, D. W. C. In New Frontiers in Asymmetric Catalysis; Mikami, K. Lautens, M., Eds.; John Wiley \& Sons: New Jersey, 2007; p 313.

11. Mayer, S.; List, B. Angew. Chem., Int. Ed. 2006, 45, 4193.

12. Frisch, M. J.; Trucks, G. W.; Schlegel, H. B.; Scuseria, G. E.; Robb, M. A.; Cheeseman, J. R.; Montgomery, J. A., Jr.; Vreven, T.; Kudin, K. N.; Burant, J. C.; Millam, J. M.; Iyengar, S. S.; Tomasi, J.; Barone, V.; Mennucci, B.; Cossi, M.; Scalmani, G.; Rega, N.; Petersson, G. A. Nakatsuji, H. Hada, M.; Ehara, M. Toyota, K.; Fukuda, R.; Hasegawa, J.; Ishida, M.; Nakajima, T.; Honda, Y.; Kitao O.; Nakai, H.; Klene, M.; Li, X.; Knox, J. E.; Hratchian, H. P.; Cross, J. B.; Bakken, V.; Adamo, C.; Jaramillo, J.; Gomperts, R.; Stratmann, R. E.; Yazyev, O.; Austin, A J.; Cammi, R.; Pomelli, C.; Ochterski, J. W.; Ayala, P. Y.; Morokuma, K.; Voth, G. A.: Salvador, P.; Dannenberg, J. J.; Zakrzewski, V. G.; Dapprich, S.; Daniels, A. D. Strain, M. C.; Farkas, O.; Malick, D. K.; Rabuck, A. D.; Raghavachari, K.; Foresman, J. B.; Ortiz, J. V.; Cui, Q.; Baboul, A. G.; Clifford, S.; Cioslowski, J.; Stefanov B. B.; Liu, G.; Liashenko, A.; Piskorz, P.; Komaromi, I.; Martin, R. L.; Fox, D. J.; Keith, T.; Al-Laham, M. A.; Peng, C. Y.; Nanayakkara, A.; Challacombe, M.; Gill, P. M. W.; Johnson, B.; Chen, W.; Wong, M. W.; Gonzalez, C.; Pople, J. A. Gaussian 03, Revision C. 02; Gaussian,: Wallingford CT, 2004.

13. Becke, A. D. Phys. Rev. A 1988, 38, 3098

14. Lee, C. T.; Yang, W. T.; Parr, R. G. Phys. Rev. B 1988, 37, 785.

15. Wieczerzak, E.; Kozlowska, J.; Lankiewicz, L.; Grzonka, Z. Pol. J. Chem. 2002, 76 1693.

16. Ishihara, K.; Kurihara, H.; Matsumoto, M.; Yamamoto, H. J. Am. Chem. Soc. 1998, $120,6920$. 